This is an author produced version of a paper published in Small-scale Forestry.

This paper has been peer-reviewed and is proof-corrected, but does not include the journal pagination.

Citation for the published paper:

Gun Lidestav \& Solveig Berg Lejon. (2011) Forest certification as an instrument for improved forest management within small-scale forestry. Small-scale Forestry. Volume: 10, Number: 4, pp 410-418. http://dx.doi.org/10.1007/s11842-011-9156-0.

Access to the published version may require journal subscription. Published with permission from: Springer Netherlands.

Standard set statement from the publisher:

The original publication is available at www.springerlink.com at http://link.springer.com/article/10.1007/s11842-011-9156-0.

Epsilon Open Archive http://epsilon.slu.se 


\title{
Forest certification as an instrument for improved forest management within small-scale forestry
}

\author{
Gun Lidestav ${ }^{1}$ and Solveig Berg Lejon \\ Swedish University of Agricultural Science \\ Department of Forest Resource Management \\ S-901 83 Umeå \\ Sweden
}

\begin{abstract}
Since early 1990ties, Swedish forest land is increasingly becoming certified. Today all major forest owners have joined the Swedish FSC-standard (Forest Stewardship Council), while small-scale forest owners preferably are joining the PEFC scheme (Programme for the Endorsement of Forest Certification). With the overall aim of gaining a better insight into which small-scale forest owners that have decided to take up on forest certification, and how their forest management practices have been affected by this choice, two set of data has been analyzed; one consisting Data Base of Forest Owner Analysis (DBFOA) data relating to approximately 14000 properties whereof 1955 were found to be certified, and the other one including data from a follow up questionnaire sent out only to owners with certified forest properties. Results show that certified and non-certified forest properties are managed differently and in particular that harvesting on certified properties has increased. Differences in management seem to be connected principally to the fact that forest owners from generally more active sub-groups embrace forest certification requirements. Moreover, our results shows that economic motives for joining a certification scheme are just as prevalent as environmental motives and a majority of forest owners regard certification as something that favors profitability rather than consider it to restrict economic yield.
\end{abstract}

Key words Binary logistic regression · Data Base of Forest Owner Analysis · Forest management practices $\cdot$ Sweden

\footnotetext{
${ }^{1}$ Corresponding author: Associate Professor Gun Lidestav Dept of Forest Resource Management, Swedish University of Agricultural Sciences 90183 Umeå, Sweden

Phone: +46(0)90 7868391 Cell phone +46(0)702642101

E-mail: gun.lidestav@srh.slu.se
} 


\section{Introduction}

In the wake of national and international debates on environmental issues, and an increasing consumer demands for sustainable wood and paper products, Swedish forest land has become increasingly certified under one or more forest certification scheme. The first of these, the Forest Stewardship Council (FSC), was initiated in 1993 by a number of prominent international environmental NGOs, and excluded the direct involvement of state agencies and party-political organizations (Boström 2002, Cashore et al. 2004). In 1999, the Pan-European Forest Certification Scheme (PEFC) was launched with support from private, mainly smallscale landowners, and forest owner associations. It was subsequently renamed the Programme for the Endorsement of Forest Certification Schemes and came to include not only European forestry (Gulbrandsen 2005). Thus, both schemes were initiated by non-governmental bodies and can be regarded as voluntary, non-state market-driven governance systems (for a comprehensive comparison of FSC, PEFC and other regional certification schemes see Cashore et al. 2005). However, the Swedish state welcomed forest certification as a legitimate process and has certified its state-owned forests according to the FSC-standard (Boström 2003). All other major forest owners (including large-scale forest companies, municipalities and governmental authorities) with holdings totalling almost 11 million hectares, have also joined the Swedish FSC-standard, while PEFC scheme currently covers approximately 7.9 million hectares of certified forests, mainly of small and medium sized private forest holdings (PEFC Sweden 2009b). Some forest owners have joined both the FSC and the PEFC schemes, and according to Schlyter et al (2009) they should rather be regarded as supplementary schemes suitable for different owners and forest types than competing schemes.

Large forest owners, contractors, and wood procurement organizations, who meet the FSC or PEFC standards can become certified on an individual basis, while small forest owners and small contractors or companies can become group certified through their umbrella organizations such as their Forest Owner Association. The forest owners then bind themselves to follow the existing forest management standard, which among other things implies that at least $5 \%$ of the productive forest land should be set aside for nature conservation. Furthermore, in order to meet the PEFC standard, any forest property of 20 or more hectares must establish and follow a Green Forest Management Plan. In such a plan the forest land is classified in four target types, considering the long term goal for each forest stand. At least $5 \%$ of the property should be left untouched for nature conservation reason while some other stands may be managed for the same reasons. Other stands may be managed primarily with a 
timber production target, however still with general or enhanced environmental considerations (Glöde et al 2003).

Compared with previous forest management practices, adherence to all the commitments made under these certification standards could reduce the total harvest potential (Lundström et al. 1997, Skogsstyrelsen 2000, Jacobsson 2002). A full adoption of the FSC standard on all forest land in Sweden could, according to a scenario analysis by Eriksson et al. (2006), bring about a considerable decrease in timber supply. A quantity-decreasing effect of strict forest conservation programs on has also been indicated by Leppinän et al (2005) when studying the Finnish timber market. Further, every percentage point of protected forest land represents an estimated cost of $2600-5200$ Euro/hectare. However, the authors conclude that net incomes to small scale forest owners will remains at the same level as before conservation, due to increased timber prices.

Although the FSC standard is perceived to be somewhat more demanding than the PEFC standard in the mountainous northern part of Sweden (Schlyter et al 2009), timber supply will be considerably reduced whichever standard might be followed. A notable factor in this context, however, is that the largest forest owner association in Sweden in terms of members and processing industry, Södra skogsägarna, who have been the most successful forest owner association at introducing PEFC certification to its members, have been using an argument based on an increased timber price to promote joining the PEFC (Ek 2004). A better price for certified timber has also, according to Ek (2004), been the determining factor for certifying their forest land to the majority of Södras members with certified forest land. Moreover, the requirement to establish and follow a Green Forest Management Plan may also increase pressure to develop a more systematic and productive silviculture, which in turn is also likely to increase the willingness of forest owners to harvest and so boost the supply of timber. In fact, this reasoning has been used explicitly in the marketing of Green Forest Management Plans - "There is a method which can combine an efficient forestry with high yield and nature conservation. It is called Green Forest Management Plan. Such a plan is an investment for the future" (author's translation) (http://www.sodra.com/sv/verksamheter/Skogligatjanster/Gron-skogsbruksplan 2007-11-15). From the above arguments it may be assumed that certified forest properties whose owners follow a Green Management Plan are likely to be under more standardized management than those that are not certified. Yet, as forest certification is a comparatively new and sparsely researched phenomenon a number of basic questions remain to be examined more thoroughly: Which forest owners have decided to take 
up forest certification and what are their reasons for doing so; and subsequently, how has their forest management practice been affected by this choice? In a study of forest certification participation by forest firms in Canada, the US and Germany, Cashore et al (2005) has shown that the choice of joining a specific certification scheme is related to if certification of forest practices were perceived to lead to an improved environment or seen as necessary to lessen external lobbying pressure. Similar reasons for small scale forest owners in West Tennessee to consider certification has been reported by Mercker and Hodges (2007), but in addition expectations on increased tree farming profits and market availability is given prominence. No significant relationship between the willingness to consider forest certification and size of the forest ownership or harvest history was found in this study. In contrary, Berg and Lidestav (2009) reports that among Swedish small scale forest owners harvesting activities are more frequent on certified properties and that likelihood of certification increases with size of the forest holding. The positive relation between certification and size of the forest has also been reported by Ek (2004) in a study of small scale forest owners associated to Södra skogsägarna. Ek (2004) reported that those members with certified properties were in general somewhat younger and their properties considerably larger than the average. Compared to the entire corps of the membership, those with certified properties are more likely to be younger than the average owner, and to be men who are also resident owners. Furthermore, the majority of respondents to the survey stated that their forest management practice had not changed due to the forest certification. Söderkvist (2002) reported similar results from a more general attitude study. The concerns regarding decreased harvesting volumes, as raised by the scenario analysis of Eriksson et al. (2006), may therefore be questioned. However, there are a number of reasons why caution should be considered when making any far-reaching interpretations from these rather limited studies and why the issue should be further investigated. First, people's attitudes are not always consistent with their actual behavior. Secondly, considering the well documented heterogeneity among small-scale forest owners in Sweden (see e.g. Törnqvist 1995, Ingemarsson 2004, Lidestav \& Nordfjell 2005, Berlin et al. 2006), and the small proportion that have so far joined any forest certification scheme (Johansson \& Lidestav In press), it may be that those who have been the first to choose to enter such schemes were already managing their forests along similar lines to what is now demanded under certification. The logic of this assumption is empirically supported by results from a survey in West Tennessee, US, showing a highly significant relationship between small scale landowners willingness to consider certification and the perception that certification will give them recognition for the good forestry that they already are practicing 
(Mercker and Hodges 2007). Thirdly, the logic of forest firms varying reasons for joining a certification scheme depending on their position in the market has to some extent been contradicted by Cashore et al (2005). To conclude, forest owners' (companies) interests in forest certification can, according to Klingberg (2003), be classified according to three motives for joining a certification scheme: i) It can be regarded as an efficient instrument for improved forest management with respect to ecological, economical and social aspects; ii) It can be regarded as an instrument for communication with the company's customers and/or its consumers in a broad sense; iii) It may be part of a power game of market positions and/or influence regarding the use of forest land.

\section{Aims and delimitations}

From a sustainability point of view, the first motive mentioned above (i) is the primary motive, and is also the point of departure for the present study. This implies that our research interest focuses on non-industrial private forest land and its owners, i.e. forest owners with no direct interest in the two latter motives (ii, iii). With the overall aim of gaining a better insight into the impact of forest certification on non-industrial, private forest owners' management practices, in the present paper we investigate the following:

- Whether management, and in particular harvesting, differs between certified and noncertified forest properties.

- Whether forestry activity among owners of certified properties differs to a lesser extent than forestry activity among owners of non-certified properties: i.e. if the assumption can be confirmed that certification per se promotes a standardized behavior.

- Whether some forest owner sub-groups are more disposed than others to certify their forest land, and if so, for what reasons.

- Whether forest management practiced on certified properties results from certification, or whether owners choose to certify their property because their current practice already closely follows the certification standard.

Previous studies on Swedish, non-industrial forest owners, have indicated that the size of a property, the age and sex of the owner, whether the owner actively works their own forest land (i.e. self-active), and whether the owner is resident on their property, can all impact forestry activity and management behavior (see e.g. Törnqvist 1995, Ingemarsson 2004 , Lidestav \& Nordfjell 2005, Berlin et al. 2006). The occurrence of forest certification has 
therefore been examined according to these same categories. General silvicultural processes and harvesting activities have also been similarly analyzed according to these categories and according to whether or not forest holdings have been certified within a scheme.

\section{Material and Methods}

The analysis was performed using data held on the Swedish Data Base for Forest Owner Analysis (DBFOA) Berg Lejon et al (In press). It contains survey data regarding cuttings and silviculture gathered by the Swedish Forest Agency. The survey was undertaken using a standardized written postal questionnaire and responded to by individual forest owners with guidance from a forest ranger at the Swedish Forest Agency. The sample of forest properties included in the survey is a stratified random sample, stratified by county and area ${ }^{2}$, from the target population of small-scale forest management units in Sweden. A comprehensive description of the methodology and the database is reported in Berg Lejon et al. (In press). With respect to certified and non-certified forest properties: target population sizes, sample sizes, number of respondents and respondent rates for the period 1999-2006 are presented in Table 1.

Table 1 Small-scale forest owner's survey, total number of management units, samples, respondents and percentage of answers for 1999-2006

\begin{tabular}{ccccc}
\hline Year of activity & Population size & Sample size & $\begin{array}{c}\text { Number of } \\
\text { respondent }\end{array}$ & $\begin{array}{c}\text { Percentage of } \\
\text { answers }\end{array}$ \\
\hline 1999 & 202480 & 2235 & 1902 & 85 \\
2000 & 200379 & 2237 & 1864 & 83 \\
2001 & 199458 & 2239 & 1919 & 86 \\
2002 & 199194 & 2236 & 1911 & 86 \\
2003 & 199569 & 2247 & 1923 & 86 \\
2004 & 198056 & 2240 & $1192^{3}$ & 53 \\
2005 & 197033 & 2229 & 1732 & 78 \\
2006 & 196169 & 2192 & 1680 & 77 \\
\hline
\end{tabular}

Information regarding forest certification has been reported since 1999. This implies that data concerning forest certification (or non-certification) relating to approximately 14,000

\footnotetext{
${ }^{2}$ Area classes in 1999-2003 were: 5-25 ha, 25-49 ha, 50-99 ha, 100-199 ha, 200-399 ha, 400-999 ha and $\geq 1000$ ha; and in the years 2004-2006 were: 5-49 ha, 50-199 ha, 200-999 ha and $\geq 1000$ ha.

${ }^{3}$ The catastrophe due to the severe storm 'Gudrun', is reflected in the significant drop in the number of respondents for the year 2004 (53\%).
} 
properties are at present included in the database and thus in this analysis. Of these forest properties, 1955 were found to be certificated. Moreover, for the owner to whom the questionnaires were addressed, the database contains information on their sex and age, whether or not they are resident within the same municipality as the management unit, and to what extent self-activity has occurred on the management unit. Other information also reported in the database relate to: silviculture, area and volume for final felling, thinning, other cuttings, property area, cleaning, scarification, planting, supplementary planting, sowing and fertilization. By linking forest activity to forest certification and owner data, we have tried to clarify, by the use of z-tests, whether there are any differences between the categories of certified and non-certified forest management units. Throughout the paper the level of significance is set at 5\%. In other words: have owners' behaviors in forest management become more standardized through joining a forest certification scheme?

To investigate whether forest owners really change their behavior regarding forest management as a consequence of forest certification, or if certification only preferentially selects a group with a different behavior, a follow-up survey with supplementary questions concerning forest certification was needed. It was only sent. Therefore a supplementary questionnaire was sent by mail in the first week of February 2009 to forest owners who had reported that their management units were certified in 2005 and/or 2006. Just less than $50 \%$ of the first send-out was answered. A reminder was sent out at the beginning of March, following which the total percentage answered was $71 \%$. In total the questionnaire was sent to 637 owners of whom 226 refers to the 2005 survey and 223 to the 2006 survey.

To examine whether the degree of harvesting and silvicultural activity after certification is affected by different motives for certification or whether other explanatory variables are simply differently distributed between forest owners that has become more active or those who reported no changed, binary logistic regression was used. The variable to be explained is dichotomous, e.g. equal to 1 if forest owner has become more active and equal to 0 if not. The explanatory variables were reasons for certification and given by the forest owner as answers to a multiple choice question. The alternatives given - without any further explanation from our side - were environmental motives, economical motives, moral motives respectively influence from a Forest Owner Association. The two latter motives were merged and defined as social motives. As the respondents were allowed to indicate more than one motive combinations of motives exists; environmental \& economical, environmental \& social, economical \& social and environmental \& social \& economical. Further - since the 
stratification of the data was not taken into account when the logistic regression was

performed - forest holding size and region (Södra region respectively

Mellanskog/Norra/Norrskog region) were included in the model.

\section{Results}

At the national level, $17 \%$ of all management units are certified to one of the present standards. The PEFC is by far the most common, accounting for $88 \%$ of all certified management units, of which $73 \%$ are found in the region where the Södra forest owner association organizes some 50,000 forest owners. In this region, 19\% of management units are certified, while only $7 \%$ are certified in Mellanskog region, $5 \%$ in Norra region, and 2\% in the most northerly region, Norrskog.

Further analysis of the extent of certification in different ownership categories, agrees with the findings of Ek (2004) that larger management units are more likely to be certified than smaller ones, irrespective of the addressed owner's sex, and their reported residence and activity in forestry on their property (Fig. 1). A z-test indicated a significant difference between the total acreage of certified and non-certified units, and that units owned by men are more likely to be certified than units owned by women. However, although not tested, owners who themselves were actively engaged in forestry on their own holdings seem more likely to be certified within a scheme than owners who do not perform any practical forestry work themselves. Owners of certified and non-certified management units did not differ significantly in age. 


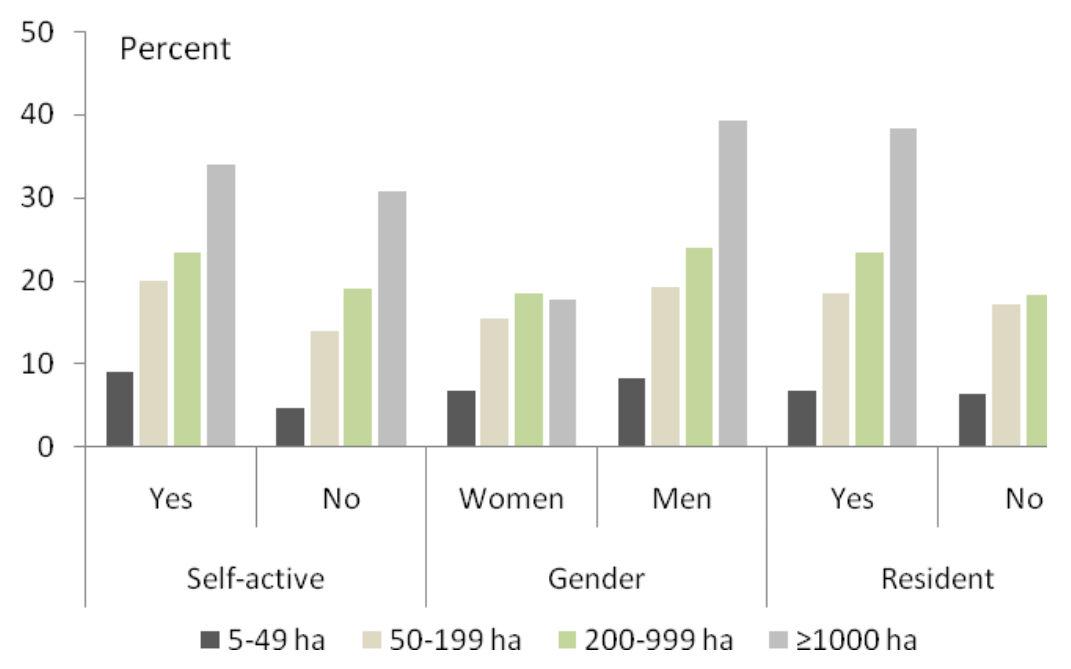

Fig. 1 Share of certified management units by size and ownership category

Over the period examined, harvesting and silvicultural activity was more frequent on certified than on non-certified management units. Since the pattern was similar irrespective of ownership category, it seems that the act of certification has more influence on whether such activity occurs than does the owner's sex, residency, or active engagement in forestry (Fig. 2). However, activity tends to decrease with time since first being certified. Forest owners who certified their management units less than five years ago formed 56\% of the total, accounted for $65 \%$ of all final felling, $58 \%$ of all thinning, $57 \%$ of all other cuttings, $59 \%$ of all cleaning, $60 \%$ of all planting, and $60 \%$ of all scarification. By contrast, forest owners who certified their management units five years ago or more, who comprised the remaining $44 \%$ of the total, accounted for $35 \%$ of all final felling, $42 \%$ of all thinning, $43 \%$ of all other cuttings, $4 \%$ of all cleaning, $42 \%$ of all planting, and $40 \%$ of all scarification. 


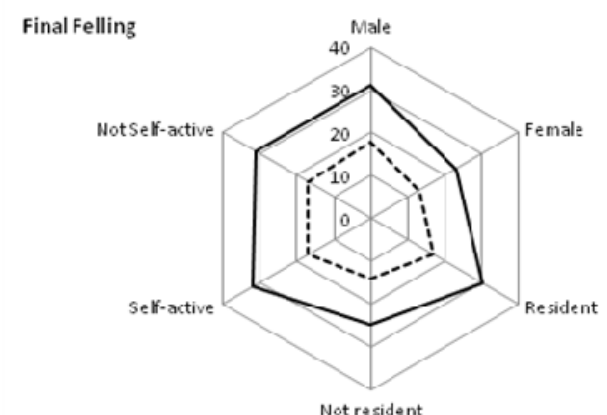

Not resident

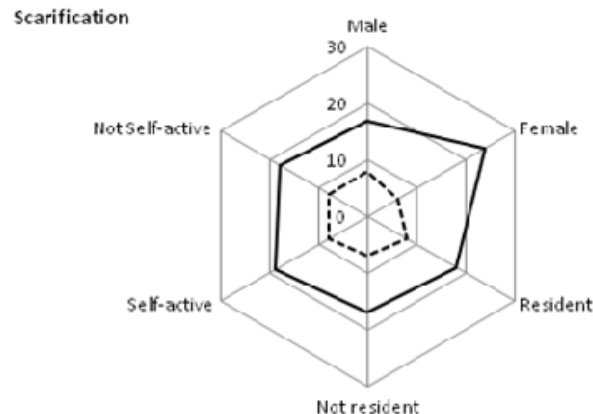

Cleaning

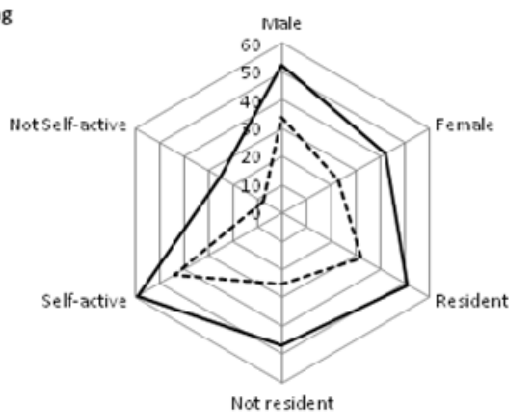

Thinning

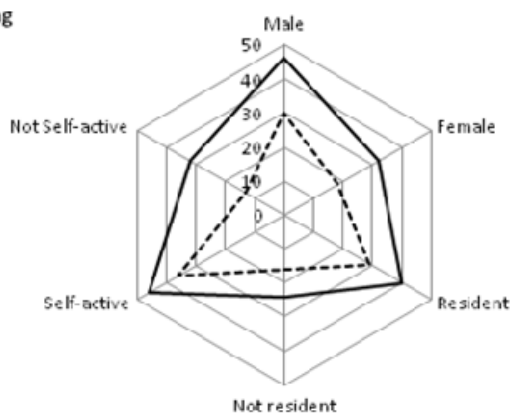

Forest Certification

Yes

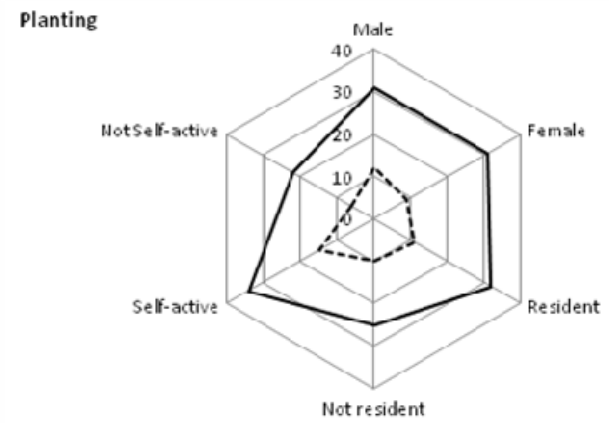

Fig. 2 Forestry activities (percentages) on certified and non-certified management

The area in which forestry activity occurred, and the volume of timber extracted from properties were significantly greater in certified forest management units than non-certified units, especially in relation to planting and thinning (Table 2, left column). However, to some extent this appears to be due to the generally larger size of certified management units.

A comparison based on the ratio between 'Treated area/Total area' (Table 2) shows that the differences in levels of activity diminish, and that for final felling and cleaning, no significant difference can be discerned. Nevertheless, activities in thinning, scarification, and planting were still significantly higher on certified than non-certified units. With respect to the variable 'Extracted volume/Treated area', a significantly higher harvest was reported on certified management units in both final felling and thinning, indicating that stands are denser on certified management units. Whether this is due to better site conditions or more intense management cannot be determined from our data. 
Table 2 Results from z-test comparison between activities on certified and non-certified forest properties

\begin{tabular}{|c|c|c|c|c|c|c|c|}
\hline \multirow[t]{2}{*}{ Activity extent } & \multirow{2}{*}{$\begin{array}{c}\text { Statistical } \\
\text { significance }\end{array}$} & \multicolumn{2}{|c|}{$\begin{array}{l}\text { Forest certification } \\
\text { and activity average }\end{array}$} & \multirow{2}{*}{$\begin{array}{l}\text { Treated area / } \\
\text { Total area }\end{array}$} & \multirow{2}{*}{$\begin{array}{c}\text { Statistical } \\
\text { significance }\end{array}$} & \multicolumn{2}{|c|}{$\begin{array}{l}\text { Forest certification } \\
\text { and activity average }\end{array}$} \\
\hline & & Yes & No & & & Yes & No \\
\hline Final felling area (ha) & $*$ & 0.85 & 0.56 & Final felling & & 0.01 & 0.01 \\
\hline Final felling volume $\left(\mathrm{m}^{3}\right)$ & * & 194.60 & 116.36 & Thinning & $*$ & 0.04 & 0.03 \\
\hline Thinning area (ha) & $*$ & 2.10 & 1.08 & Soil scarification & $*$ & 0.01 & 0.01 \\
\hline Thinning volume $\left(\mathrm{m}^{3}\right)$ & $*$ & 102.86 & 50,44 & Planting & $*$ & 0.01 & 0.01 \\
\hline Other cuttings volume $\left(\mathrm{m}^{3}\right)$ & $*$ & 46.55 & 25.66 & Cleaning & & 0.02 & 0.02 \\
\hline Soil scarification area (ha) & $*$ & 0.63 & 0.38 & $\begin{array}{l}\text { Extracted volume } \\
\text { /Treated area }\end{array}$ & & & \\
\hline Planting area (ha) & $*$ & 0.58 & 0.35 & Final felling & $*$ & 69.08 & 41.67 \\
\hline Cleaning area (ha) & $*$ & 1.63 & 0.98 & Thinning & $*$ & 21.83 & 13.78 \\
\hline
\end{tabular}

* Significant is set at $5 \%$

Regarding the assumption that certification per se promotes a standardized behavior, our results show that, irrespective of region, owner's sex, or owner's residency on the property, in terms of thinning (treated area/total area, or treated volume/treated area), less disparity was found among certified management units than among non-certified units (Table 3). However, in final felling, no such differences in standardization were found between certified and noncertified units. This may reflect the fact that final felling, apart from deciding whether or not to leave seed trees, is in any case a rather standardized practice.

Table 3 Results from z-test, comparison of activities among different sub-groups of certified and non-certified forest properties

\begin{tabular}{|c|c|c|c|c|c|c|}
\hline & \multicolumn{3}{|c|}{$\begin{array}{c}\text { Forest certification } \\
\text { Activity average and Statistical significance }\end{array}$} & \multicolumn{3}{|c|}{$\begin{array}{l}\text { No forest certification } \\
\text { Activity average and Statistical significance }\end{array}$} \\
\hline & South North & $\begin{array}{c}\text { Men } \\
\text { Women }\end{array}$ & $\begin{array}{c}\text { Resident } \\
\text { Not Resident }\end{array}$ & South North & $\begin{array}{c}\text { Men } \\
\text { Women }\end{array}$ & $\begin{array}{c}\text { Resident } \\
\text { Not Resident }\end{array}$ \\
\hline $\begin{array}{l}\text { Treated area / } \\
\text { Total area } \\
\text { in thinning }\end{array}$ & $\begin{array}{c}0.04 \underset{*}{0.03} \\
\end{array}$ & $\begin{array}{c}0.050 .03 \\
*\end{array}$ & $\begin{array}{c}0.040 .03 \\
*\end{array}$ & $\begin{array}{c}0.03 \\
*\end{array} 0.02$ & $\underset{*}{0.08} 0.02$ & $\begin{array}{c}0.030 .02 \\
*\end{array}$ \\
\hline $\begin{array}{l}\text { Treated volume } \\
\text { / Treated area } \\
\text { in final felling }\end{array}$ & $\begin{array}{c}76.7638 .52 \\
*\end{array}$ & 78.0967 .41 & 78.2070 .41 & $\begin{array}{c}46.1635 .50 \\
*\end{array}$ & 43.2739 .35 & 43.1749 .03 \\
\hline $\begin{array}{l}\text { Treated volume } \\
\text { / Treated area } \\
\text { in thinning }\end{array}$ & 22.5919 .12 & 23.1020 .64 & 16.2413 .84 & $15.06 \underset{*}{10.84}$ & 14.5311 .62 & $\begin{array}{c}16.079 .96 \\
*\end{array}$ \\
\hline
\end{tabular}


A comparison by area classes showed that certification does seem to standardize behavior with respect to thinning (Table 4).

Table 4 Results from z-test, comparison of activities - Treated volume / Treated area in thinning - and p-value among different area classes of certified and non-certified forest properties

\begin{tabular}{|c|c|c|}
\hline \multirow[t]{2}{*}{ Area class ${ }^{4}$} & \multicolumn{2}{|c|}{$\begin{array}{l}\text { Forest certification } \\
\text { Activity average and Statistical } \\
\text { significance }\end{array}$} \\
\hline & Yes & No \\
\hline I och II & 18.4318 .82 & $7.01 \quad 10.55$ \\
\hline I och III & $18.43 \quad 20.64$ & $7.01 \quad 14.16$ \\
\hline I och $I V$ & $18.43 \quad 23.52$ & $7.01 \quad 15.72$ \\
\hline II och III & $18.82 \quad 20.64$ & $10.55 \quad 14.16$ \\
\hline II och $I V$ & $18.82 \quad 12.52$ & $18.82 \quad 15.72$ \\
\hline III och IV & $\begin{array}{rr}20.64 & 23.52 \\
& *\end{array}$ & $14.16 \quad 15.72$ \\
\hline
\end{tabular}

* Significant is set at $5 \%$

When asked what their motives were for having their forest certified, environmental and economical motives predominated, with one interesting exception (Table 5). Forest owners with small holdings generally mentioned being influenced by the Forest Owner Association and to a minor extent by moral motives, while owners of larger management units cited environmental and economical motives. Women and men were equal in claiming economical motives, but men more often cited environmental motives. Resident and non-resident owners equally claimed environmental motives, while resident owners more often claimed economical motives. Economical and environmental motives were equally claimed by owners regardless of their level of active engagement in forestry on their own holdings.

\footnotetext{
${ }^{4}$ Area classes: I: 5-49 ha, II: 50-199 ha, III: 200-999 ha, IV: $\geq 1000$ ha
} 
Table 5 Reported motives for joining forest certification schemes among different categories of forest owners (percent). Note that the sum can exceed 100 percent as the respondents could indicate more than one motive.

\begin{tabular}{|c|c|c|c|c|c|c|c|c|c|}
\hline $\begin{array}{l}\text { Motives for forest } \\
\text { certification }\end{array}$ & 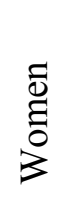 & $\sum_{\Sigma}^{\overline{0}}$ & 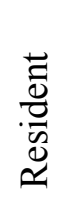 & 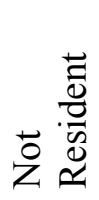 & 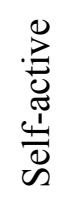 & 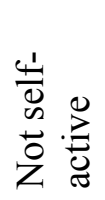 & 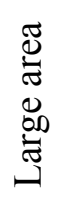 & 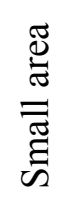 & $\bar{Z}$ \\
\hline Environmental motives & 37 & 49 & 39 & 37 & 48 & 40 & 54 & 0 & 34 \\
\hline Economical motives & 50 & 49 & 42 & 34 & 51 & 44 & 54 & 0 & 36 \\
\hline Moral motives & 12 & 8 & 7 & 8 & 9 & 10 & 10 & 30 & 7 \\
\hline $\begin{array}{l}\text { Influence from Forest Owner } \\
\text { Association }\end{array}$ & 27 & 31 & 27 & 17 & 31 & 26 & 30 & 85 & 22 \\
\hline
\end{tabular}

As a whole, approximately a third of forest owners claim to have become more active since certification took place, while two-thirds continued to behave in the way they had done before certification (Table 6). However, women, and owners of small management units, who are generally less active, more often increased their level of activity compared to men and owners of large management units. (c.f. Fig 2).

Table 6 Reported changes (percent) in management activity among different categories of forest owners.

\begin{tabular}{|c|c|c|c|c|c|c|c|c|c|c|c|}
\hline $\begin{array}{l}\text { Changes in forest } \\
\text { management activity }\end{array}$ & 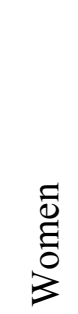 & $\sum_{\Sigma}^{0}$ & $\begin{array}{l}\overrightarrow{0} \\
\frac{\vec{v}}{\vec{v}} \\
\tilde{v}\end{array}$ & 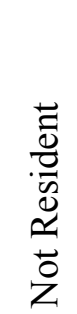 & 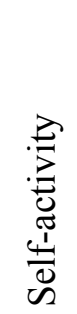 & 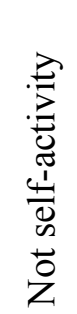 & 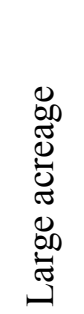 & 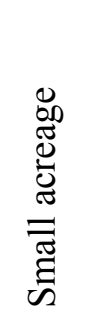 & 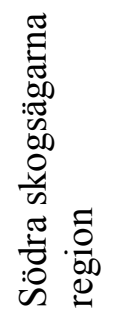 & 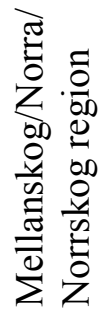 & \& \\
\hline Became more active & 36 & 28 & 29 & 29 & 32 & 20 & 25 & 31 & 31 & 24 & 31 \\
\hline No difference & 53 & 65 & 63 & 66 & 65 & 58 & 68 & 62 & 62 & 69 & 66 \\
\hline
\end{tabular}

While $37 \%$ of forest owners considered certification to have a positive effect on profitability, $28 \%$ thought that it had had no noticeable effect, $27 \%$ had no opinion, and $5 \%$ considered any effect to be negative. Further, almost $75 \%$ of forest owners reported that forest certification had increased their consideration of retention trees, dead wood and deciduous trees (not presented in tables). A majority (76\%) also regarded forest certification as a proper way of achieving a sustainable forestry ( = all "Yes" answers), with the most frequent response $(35 \%)$ being that certification guaranteed a good balance between timber production, conservation and social interests (Fig. 2). 


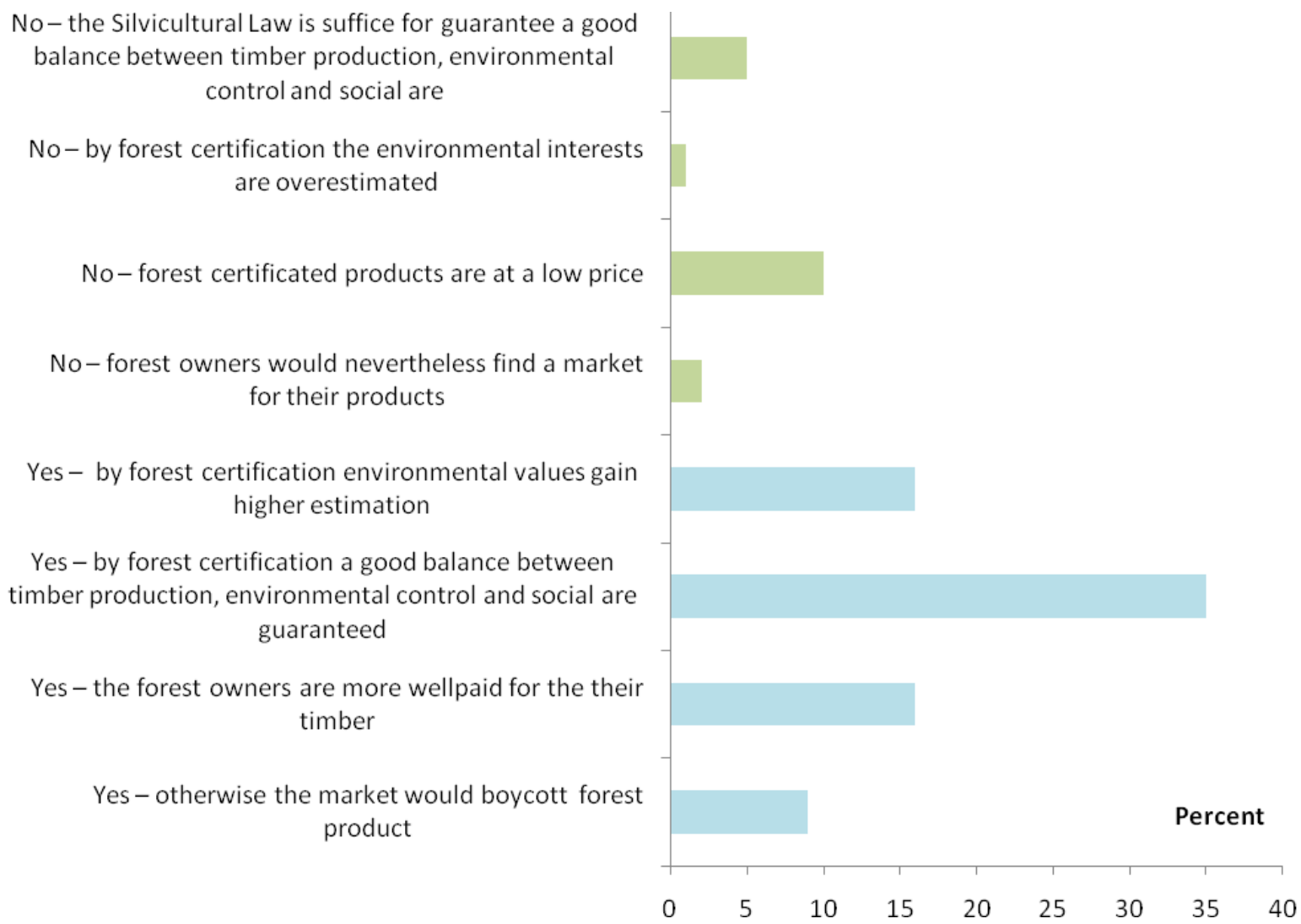

Fig. 2 Proportion of forest owners that considered certification as a proper way to achieve a sustainable forestry.

Over time, the attitude towards forest certification has improved. After completing certification, $85 \%$ of the respondents stated that they had a positive attitude towards the scheme, compared to $65 \%$ who felt positively towards it when they decided to join. Of the $29 \%$ who claimed that they had no opinion at the time of joining, $68 \%$ had become positive, while $26 \%$ still held no opinion, and $6 \%$ were negative. (Not presented in table.) Although the majority stated that they had not become more active, it seems that there was a general increase in management activity. The $55 \%$ of all respondents who identified themselves as forest owners with "well managed forests" as a primary objective had become more active than the $37 \%$ of all respondents who cited "good profitability" as their primary objective (Table 7). Thus, it seems that those motivated by a desire for "well managed forests" were prompted into activity more than those who cited profitability as their main motive. 
Table 7 Percentage of forest owners that reported higher activity after certification

\begin{tabular}{lrr}
\hline Owner categories & $\begin{array}{c}\text { Good } \\
\text { economic } \\
\text { profit }\end{array}$ & $\begin{array}{c}\text { Well } \\
\text { managed } \\
\text { forests }\end{array}$ \\
\hline Small: 0-99 ha & 18 & 27 \\
Large: $\geq 100$ ha & 8 & 8 \\
Men & 20 & 24 \\
Women & 6 & 12 \\
Resident & 23 & 27 \\
Not resident & 3 & 9 \\
Self-active & 23 & 29 \\
Not self-active & 2 & 7 \\
South of Sweden & 23 & 31 \\
North of Sweden & 3 & 5 \\
\hline
\end{tabular}

The estimated logistic model showed that with the exception for forest holding size, there were no differences between those who had become more active and those who reported no change in silvicultural activity or forestry behavior for different motives for certification (Table 8). The holding size turned out to be the only explanatory variable that was significant and on the contrary to what could be expected from previous result (see Fig. 1) the degree of activity increment decreased with holding size. Further, it was expected that region (Södra region respectively Mellanskog/Norra/Norrskog) should contribute to the explanation of increased activity, as the introduction of certification has been considerable more successful in Södra region. However, no such "Södra effect" was found. Neither did motives or combination of motives seems to influence the activity increment. 
Table 8 Forest activity: synthesis of logistic regression analysis

\begin{tabular}{lrrr}
\hline Predictor & Coefficient & SD & p-value \\
\hline & & & \\
Forest activity (1=more active, $0=$ no change) & & & \\
Constant & -2.105 & 1.106 & 0.057 \\
Region (Södra region respectively Mellanskog/Norra/Norrskog) & 0.121 & 0.322 & 0.706 \\
Environment & 1.322 & 1.082 & 0.222 \\
Economic & 1.188 & 1.086 & 0.274 \\
Social & 1.101 & 1.084 & 0.310 \\
Forest holding size & -0.001 & 0.001 & 0.026 \\
Environment * Economic & -0.888 & 1.141 & 0.436 \\
Environment * Social & -2.768 & 1.520 & 0.069 \\
Economic * Social & -0.975 & 1.192 & 0.414 \\
Economic * Environment * Social & 2.515 & 1.662 & 0.130 \\
& & & \\
Constant & -0.883 & 0.177 & 0.000 \\
Environment & 0.346 & 0.235 & 0.141 \\
Holding size & -0.001 & 0.001 & 0.026 \\
Environment * Social & -1.810 & 1.053 & 0.085 \\
Economic * Environment * Social & 1.832 & 1.102 & 0.096 \\
& & & \\
Constant & -0.773 & 0.144 & 0.000 \\
Forest holding size & -0.001 & 0.001 & 0.032 \\
\hline
\end{tabular}

\section{Discussion and Conclusions}

Results that are based on self-reported data, as in this study, may be questionable on the grounds of there being a lack of "on-site" confirmation. A comparison of our results from the overall analysis of the Swedish Data Base for Forest Owner Analysis with results from the National Forest Inventory also suggests that the self-reported figures overstate the on-site inventory based figures. A tendency for respondents to want to please the interviewer is one likely explanation (Frey and Mertens Oishi, 1995); another may be that the forest owners overestimate the area over which a specific activity has taken place, e.g. they may report that an entire stand has been cleaned while only a part can be considered as cleaned using the NFI definitions. On the other hand, misunderstandings and deliberate false reports are reduced if forest professionals with local knowledge interview forest owners. Apart from the general tendency of overestimation, we consider our data to be high quality. The design and procedure for data collection had been pretested, found to be efficient, and performed in the same way since 1992 . A response rate of $75 \%$ or more, is considered to be very high, both in national and international contexts, and to have a high probability of producing a reliable dataset. Finally, we have no reason to believe there to be any systematic differences between forest owners with certified and non-certified properties. Regarding the follow-up survey of forest owners with certified management units only, the response rate was $71 \%$. In this case a 
mail-based procedure was used, and the respondents could only get guidance if they telephoned a member of the research team who set the questions.

Given the reliability of our data, we argue that our results show that certified and non-certified forest properties are managed differently and in particular that harvesting on certified properties has increased. Differences in management seem to be connected principally to the fact that individuals from generally more active sub-groups: i.e. men, resident owners, selfactive owners, and owners with larger forest holdings (as reported inter alia by Lidestav and Nordfjell 2005, Lindroos et al. 2005, Berlin et al. 2006), have been more willing to certify their forest. Similar to Mercker and Hodges' (2007) results from West Tennessee, many of the certified forest owners in Sweden seems to perceive the certification as recognition for the good forestry that they already are practicing, and also that there are economical and market expectations. But in contrast to the West Tennessee situation, there is an apparent positive relation between holding size and the willingness to take up forest certification in Sweden The influence of holding size previously reported by Ek (2004) and Berg Lejon and Lidestav (In press) is thus underlined by this study. Further, between $20 \%$ and $36 \%$ of owners, depending on sub-group, state that they had become more active after joining the certification scheme. However, none of the single motives or combination of motives for joining certification in the regression analysis could explain the activity increment. Holding size turned out to be the only significant explanatory variable. However, the coefficient is small and negative, indicating a lower probability for owners with larger holdings to increase their forest activity compared to owners with smaller holdings. Compared to previous results showing a positive impact of holding size on harvesting activity, this may be regarded as a paradoxical. However, it may be reasonable if we consider that the potential for activity increment is likely to be higher on smaller holdings. Further, it was expected that region (Södra region respectively Mellanskog/Norra/Norrskog) should contribute to the explanation of increased activity, as the introduction of certification has been considerable more successful in Södra region. However, no such "Södra effect" was found.

Taken together, these observations suggest that a standardization effect, although not consistent, does occur. The concerns over a potentially decreased harvest predicted in the scenarios presented by Eriksson et al. (2006) and Leppänen et al. (2005) or the estimated reduction of harvesting potential reported by Lundström et al. (1997), Skogsstyrelsen (2000), Jacobsson (2002), are thus not supported by our findings. In contrast to the Finnish situation 
reported by Leppänen et al. (2005), the certified Swedish forest owners seems to have increased their income by a larger volume harvested and a somewhat higher price for certified timber paid by some major buyers like the forest owner association Södra skogsägarna. Further, the circumstances that the certification rate is much higher in Södra skogsägarna region than in the other regions, indicates that the market situation of the major purchaser has an indirect impact on individual small scale forest owner's decision regarding certification (c.f. Klingberg 2003 and Cashore 2005). However, according to the regression analysis the probability of increased forest activity seems not to depend on in which region the certified property is located.

Considering that the forest certification process involves the establishment of a Green Forest Management Plan (GFMP) that highlights a number of measures that should be undertaken more or less urgently, it can be argued that activity is increased. Such an outcome has been reported in a study conducted in the parish of Älvdalen where the GFMP was provided en masse to the forest owners (Svensson 2002). Moreover, our results shows that economic motives for joining the certification scheme are just as prevalent as environmental motives, and many more forest owners look upon certification as something that favors profitability than consider it to be harmful. It should also be noted that forest owners who had "well managed forests" as their main objective were more likely to increase their level of activity than those who considered "good economic profit" as their main objective. Yet, more research is needed in order to fully explain the impact of forest certification on small-scale owners management behavior in general and harvesting in particular.

\section{Acknowledgments}

We gratefully acknowledge the Erik Rönnberg Foundation who financed this study. 


\section{References}

Berg Lejon, S. \& Lidestav, G. 2009. Skogscertifiering - vem, hur och varför? FaktaSkog. Nr 11 2009. Sveriges lantbruksuniversitet. Davidsssons Tryckeri AB, Växjö

Berg Lejon S, Holmgren L and Lidestav G (In press) Assessing small-scale forestry by the Data Base of Forest Owner Analysis. (Small-scale Forestry)

Berlin C, Lidestav G and Holm S (2006) Values Placed on Forest Property Benefits by Swedish Owners: Differences between Members in Forest Owner Associations and Nonmembers. Small-scale For Econ Manage Policy, 5(1):83 - 96

Boström M (2002) Skogen märks - Hur svensk skogscertifiering kom till och dess konsekvenser. Score Working Paper Series 2002:3, Stockholm: Score

Boström M (2003) How State-Dependent is a Non-State-Driven Rule-Making Project? The Case of Forest Certification in Sweden. Journal of Environmental Policy and Planning $5(2), 165-180$

Cashore B, Auld G and Newsom D (2004) Governing Through Markets - Forest Certification and the Emergence of Non-State Authority. New Haven, Yale University Press

Cashore B, van Kooten, C G and Vertinsky I, Auld G and Affolderbach J (2005) Private or self-regulation? A comparative study of certification choices in Canada, the United States and Germany. Forest Policy and Economics 7: 53-69

Ek J (2004) Certifiering och gröna skogsbruksplaner idag och i framtiden. Examensarbete 63, Sveriges lantbruksuniversitet, Institutionen för sydsvensk skogsvetenskap, Alnarp

Eriksson Ljusk O, Sallnäs O and Ståhl G (2006) Forest certification and Swedish wood supply. Forest Policy and Economics. 5:452-463

Forestry statistics (2009) Official Statistics of Sweden, Swedish University of Agricultural Sciences, Umeå, ISSN 0280-0543

Frey J H and Mertens Oishi S (1995) How to conduct interviews by telephone and in person. Sage Publications, Inc. ISBN 0-8039-5719-X

FSC - Forest Stewardship Council: www.fsc-sverige.org/Statistik/CertifikatSverige/tabid/88/Default.aspx

Glöde D, Persson A, Norstedt G and Weslien J (2003) Green forestry plans could be greener. Resultat från Skogforsk. Nr 20:2003. Uppsala (In Swedish with summary in English)

Gulbrandsen LH (2005) Sustainable Forestry in Sweden: The Effect of Competition Among Private Certification Schemes. Journal of Environment and Development, 14 (3), 338-355

Ingmarsson F (2004) Small-scale forestry in Sweden - owners' objectives, silvicultural practices and management plans. Swedish University of Agricultural Sciences, Dept of Forest Products and Markets. Dissertation. Acta Universitatis Agriculturae Sueciae Silvestria 318, Uppsala 
Johansson J and Lidestav G (2010) Can voluntary standards regulate forestry? - Assessing the environmental impacts of forest certification in Sweden, Forest Policy and Economics doi:10.1016/j.forpol.2010.11.004

Jacobsson J (2002) Assessing the Impact on Production and Costs from the Application of Forest Certification Standards. Pi Environmental Consulting, Pully, Switzerland

Klingberg T (2003) Certification of Forestry: A small-scale forester perspective. Small-Scale For Econ Manage Policy 2(3):409-421

Leppänen, J, Linden M, Uusivuori J and Pajuola H (2005) The private cost and timber market implications of increasing strict forest conservation in Finland. Forest Policy and Economics, 7:71-83.

Lidestav G and Nordfjell T (2005) A Conceptual Model for understanding Social Practices in Family Forestry. Small-scale For Econ Manage Policy, 4:391 - 408

Lindroos O, Lidestav G and Nordfjell T (2005) Swedish Non-Industrial Private Forest Owners. A survey of Self-employement and Equipment Investments. Small-scale For Econ Manage Policy, 4:409 - 42

Lundström A, Nilsson P and Ståhl G (1997) Certifieringens konsekvenser för möjliga framtida uttag av industri- och energived - en pilotstudie. Arbetsrapport 23, Sveriges lantbruksuniversitet, Institutionen för skoglig resurshushållning och geomatik, Umeå

Mercker, D C and Hodges D G (2007) Forest Certification and Nonindustrial Private Forest Landowners: Who Will Consider Certifying and Why? Journal of Extension. August 2007 // Volume 45 // Number 4 // Research in Brief // 4RIB6.

PEFC - Programme for the Endorsement of Forest Certification schemes: www.pefc.se

Schlyter P, Stjernquist I and Bäckstrand K (2009) Not seeing the forest for the trees? The environmental effectiveness of forest certification in Sweden. Forest Policy and Economics 11, 375-382.

Skogsstyrelsen (2000) Skogliga konsekvensanalyser 1999. Rapport nr 2, Jönköping

Svensson H (2002) The importance of forest management plan for private forest activity in Älvdalen. Master thesis No 2. Swedish University of Agricultural Sciences. Department of forest management and products, Uppsala (In Swedish with English summary)

Swedish Data Base for Forest Owner Analysis: www.slu.se/?id=198

Söderkvist K (2002) Att vara eller inte vara certifierad? - Det är frågan. En enkätstudie av privata skogsägare i Sverige och deras attityd till skogscertifiering. Examensarbete nr 5, Sveriges lantbruksuniversitet, Institutionen för skogsskötsel, Umeå

Södra skogsägarnas Gröna skogsbruksplan: www.sodra.com/sv/verksamheter/Skogligatjanster/Gron-skogsbruksplan 
Törnqvist T (1995) Skogsrikets arvingar. En sociologisk studie av skogsägarskapet inom privat enskilt skogsbruk. Forskningsstiftelsen SAMU, Uppsala, No. 6, 423 pp 